\title{
Iron Speciation and Its Biological Availability in Seawater: A Workshop
}

\author{
Mark L. Wells and Kenneth W. Bruland \\ Award \#: OCE9314179
}

The controversy surrounding iron limitation of phytoplankton in the open ocean and its potential role in regulation global climate, both in the present and in the past, has highlighted how little is known about the speciation and biological availability of iron in seawater. This workshop brought together chemists having theroretical and analytical expertise in iron chemistry together with biologists having expertise in the algal physiological aspects of iron. The result was a new paradigm for Fe biogeochemistry which for the first time highlights the unique complexity of the biological and chemical interactions regulating the behavior and impact of this element in marine ecosystems. Of the many issues discussed by the participants, five key questions emerged as the most pressing at this time:

1.What are the sources and sinks of new and regenerated soluble Fe in the upper ocean?

2.What is the chemical speciation of Fe among the soluble, colloidal and particulate fractions, including the rates and mechanisms of transformations among these forms?

3.What are the inter-relationships between the chemical speciation of Fe and the microbial community (e.g., how the chemical speciation influences Fe uptake by the biotic community and how the community influences $\mathrm{Fe}$ speciation)?

4.How do microbes adapt biochemically and physiologically to variations in $\mathrm{Fe}$ availability in the ocean?

5. What ecological and biogeochemical implications arise from temporally and spatially changing Fe supply and availability in the oceans?

The discussions lead to the conclusion that no one analytical measure can quantify biologically available iron. Measurement of iron availability in natural waters awaits better characterization of the marine chemistry of iron in conjunction with exploration of the uptake strategies used by differen members of the algal community. 


\section{DISCLAIMER}

This report was prepared as an account of work sponsored by an agency of the United States Government. Neither the United States Government nor any agency thereof, nor any of their employees, make any warranty, express or implied, or assumes any legal liability or responsibility for the accuracy, completeness, or usefulness of any information, apparatus, product, or process disclosed, or represents that its use would not infringe privately owned rights. Reference herein to any specific commercial product, process, or service by trade name, trademark, manufacturer, or otherwise does not necessarily constitute or imply its endorsement, recommendation, or favoring by the United States Government or any agency thereof. The views and opinions of authors expressed herein do not necessarily state or reflect those of the United States Government or any agency thereof. 


\section{DISCLAIMER}

Portions of this document may be illegible in electronic image products. Images are produced from the best available original document. 